\title{
Revision Article
}

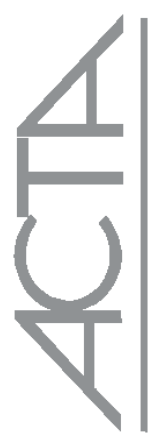

\section{Risk factors for alcohol dependence in adolescents*}

\author{
Fatores de risco para dependência de álcool em adolescentes \\ Factores de riesgo en adolescentes con dependencia al alcohol
}

\author{
Leandro Rozin ${ }^{1}$ Ivete Palmira Sanson Zagonel ${ }^{2}$
}

\begin{abstract}
Objective: To identify risk factors for alcohol dependence during adolescence. Methods: Integrative review of 21 articles published between 2000 and 2009, captured in the LILACS, BVS, MEDLINE, COCHRANE and IBECS databases, with keywords: adolescence, risk for dependence, and alcohol . Results: There is evidence that alcohol is the most consumed drug by adolescents, with initiation between 14 and 16 years. Risk factors for dependency are related to early onset of use, media influence, troubled relationship with parents, use by family member, sexual abuse, domestic violence, low self-esteem, curiosity, and peer pressure, among others. The articles pointed to genetic vulnerability to alcohol dependence and controversies in relation to gender and social class. Conclusion: Health services should incorporate preventive strategies for identifying risk for dependency, control and monitoring specific to the group of dependent adolescents.
\end{abstract}

Keywords: Adolescent; Risk factors; Alcoholism; Vulnerability

\section{RESUMO}

Objetivo: Identificar os fatores de risco para dependência do álcool na adolescência. Métodos: Revisão integrativa com 21 artigos publicados entre 2000 e 2009, capturados nas bases de dados LILACS, BVS, MEDLINE, COCHRANE e IBECS com as palavras-chave: adolescência, risco para dependência e álcool. Resultados: Há evidências de que o álcool é a droga mais consumida por adolescentes, com início entre 14 a 16 anos. Os fatores de risco para dependência estão relacionados ao início precoce do uso, influência da mídia, relacionamento conturbado com os pais, uso por membro da família, abuso sexual, violência doméstica, baixa autoestima, curiosidade, pressão de colegas, entre outros. Apontam a vulnerabilidade genética para a dependência do álcool e controvérsias em relação ao gênero e classe social. Conclusão: Os serviços de saúde devem incorporar estratégias preventivas de identificação de riscos para a dependência, controle e acompanhamento específicos ao grupo de adolescentes dependentes.

Descritores: Adolescente; Fatores de risco; Alcoolismo; Vulnerabilidade

\section{RESUMEN}

Objetivo: Identificar los factores de riesgo en adolescentes con dependencia al alcohol. Métodos: Revisión integrativa realizada con 21 artículos publicados entre 2000 y 2009, identificados en las bases de datos LILACS, BVS, MEDLINE, COCHRANE e IBECS con las palabras-clave: adolescencia, riesgo a dependencia y alcohol. Resultados: Hay evidencias de que el alcohol es la droga más consumida por adolescentes, con inicio entre 14 a 16 años. Los factores de riesgo para la dependencia están relacionados al inicio precoz del uso, influencia de los medios de comunicación, relacionamiento conturbado con los padres, uso por un miembro de la familia, abuso sexual, violencia doméstica, baja autoestima, curiosidad, presión de colegas, entre otros. Apuntan la vulnerabilidad genética para la dependencia al alcohol y controversias en relación al género y clase social. Conclusión: Los servicios de salud deben incorporar estrategias preventivas de identificación de riesgos para la dependencia, control y acompañamiento específicos al grupo de adolescentes dependientes.

Descriptores: Adolescente; Factores de riesgo; Alcoholismo; Vulnerabilidad

\footnotetext{
* Study conducted at the Faculdades Pequeno Principe (FPP), Curitiba (PR), Brazil, in the course of the Master's Programme of Graduate Studies in Biotechnology applied to the health of children and adolescents.

${ }^{1}$ Graduate Student (Master's) Programme of Graduate Studies in Biotechnology applied to the bealth of children and adolescents, Faculdades Pequeno Principe (FPP), Curitiba (PR), Brazil

${ }^{2}$ Professor, Programme of Graduate Studies in Biotechnology applied to the health of children and adolescents, Faculdades Pequeno Principe (FPP), Curitiba (PR), Brazil
} 


\section{INTRODUCTION}

Adolescence is the period in which the structuring of each being occurs, as if it were a second birth; but this phase needs care and educational activities different from those dedicated to the child ${ }^{(1)}$. In this step, the individual ceases to only live with the family, and begins to live depending on his friends also, inserting himself into the social group as a means of personal identification. After puberty, he gradually changes his way of being, in movements that start internally and then are externalized, causing the teen to seek the way in which he will be identified ${ }^{(2)}$. The changes that permeate the transition process to the adolescent phase are numerous, such as physical, social, psychological, spiritual, cultural, among others. For this article, the emphasis is on insertion of the adolescent into the social environment, including different possibilities, inside and outside of the family, which may contribute to or be related to the initiation of alcohol use.

The introduction of adolescents into the social environment, when they begin to leave the family context, puts them into different situations, among which is the contact with alcohol. This is a socially accepted drug across all social levels, with easy access and the potential, according to their initial reactions, for instantaneous well-being as a form of a resolution of uncertainty and conflicts, but also to commemorate happy and pleasant moments. However, one must consider the damages that contact with drinking can lead to in adolescents that are related to violence, including: sexual abuse, contamination by STDs, unwanted pregnancy, behavioral and conduct disorders, school absenteeism, learning disabilities, family problems, job loss, financial loss, and accidental death ${ }^{(3)}$.

The preference for alcohol consumption by adolescents occurs due to the effect of the substance that, at the beginning, is well-being. It also provides satisfaction, easy insertion into the group with their friends, and serves as a source of stress relief in relation to family and school factors ${ }^{(4)}$. Increasingly common in adolescence, alcohol use therefore entails physical, mental and social consequences, and is considered a serious public health problem.

According to the Fifth National Survey on Psychotropic Drug Use (CEBRID) conducted in 2004, with 48,155 students in elementary and middle school in 27 Brazilian capitals, it was found that $65.2 \%$ had consumed alcohol at some point in life. Furthermore, comparing studies of home surveys in the age group of 12 to 65, of 2001 and 2005, we detected an increase of $1.1 \%$ in the use of alcohol ${ }^{(5)}$.

In Brazil, in 2006, a survey conducted by CEBRID revealed that of adolescents between 12 and 17 years,
$48.3 \%$ had consumed alcohol at some time in their life. Of these, $14.8 \%$ drink regularly and $6.7 \%$ are addicted to alcohol, which makes the drug the most used by teenagers that have early exposure ${ }^{(6)}$.

Alcohol is the most widely used psychoactive drug in the majority of countries, both for celebration, and for suffering, because it frees inhibitions. People consume it to relax and have fun. For many, drinking is a companion to social events and their consumption implies relatively low risks to the drinker and to others. But, its use may be responsible for many damages in social and individual spheres. After tobacco, it is the second leading cause of drug-related deaths ${ }^{(7)}$.

It is important to maintain a comprehensive and significant policy of public health, which should have as a priority to change the amount of alcohol consumed, patterns of consumption and subsequent damage ${ }^{(7)}$. The International Harm Reduction Association (IHRA) defines reduction as policies, programs and practices that attempt to mainly reduce the negative consequences related to health, and the social and economic impacts of substances that alter the temperament for the drug users, their families and communities ${ }^{(7)}$. Harm reduction, although it has been traditionally identified with illicit drugs, also applies to alcohol and other substances such as tobacco.

The earlier consumption begins, the greater the probability that the adolescents will become dependent. In addition, with constant use, the body creates tolerance for the drug, and to achieve satisfaction (such as the initial effects) it is necessary to increase the doses, which, as a result of continual use, leads to alcohol dependency ${ }^{(5)}$.

The risk for dependency is interlinked to factors of exposure, genetics, neurobiology, behavior (personality) and experiences in the environment, which predispose the onset and continuation of substance use. Over the years, alcohol dependency settles on the individual and is identified when there is loss of control over the decision to drink and the individual suffers the symptoms of drug withdrawal ${ }^{(5)}$.

Therefore, by identifying the risks for alcohol dependency to which adolescents are exposed, it is possible to intervene through actions specific to that group, that are capable of inhibiting / preventing substance use and interfering with the future dependency that can occur. Thus, this study aimed to identify risk factors that contribute to dependency on alcohol among adolescents.

\section{METHODS}

The method of integrative literature review sought to answer the following guiding question: "What is the evidence in the literature about the risk factors for dependency on alcohol among adolescents?" This method gathers and con- 
templates the scientific knowledge produced, through the analysis of the results previously seen in studies by researchers in the area.

The searches covered publications between the years 2000 and 2009 in electronic databases, such as: LILACS, BVS, MEDLINE, COCHRANE, IBECS in the Portuguese, English and Spanish languages, using as keywords: adolescence, risk for dependence, and alcohol.

As inclusion criteria, the articles published in Portuguese, English and Spanish were used; and as exclusion criteria, these were articles that were not available online or in national libraries, in addition to not presenting data related to and consistent with the risk for dependency on alcohol.

Although there are differences in the development of integrative methods of review, there are standards to be followed. In developing this review, we used five steps: defining the guiding question for the review; selection of studies that formed the sample; defining the characteristics of studies; analysis and interpretation of the results; and, reporting of the review ${ }^{(8-9)}$.

After reading in full each of the selected articles, a data collection instrument was completed, constructed by the authors of this article, containing: year of publication, identification of the journal, authors, type of study, subjects, sample size, instrument used to measure risk of use or dependency on alcohol, results, and recommendations proposed in the studies.

\section{RESULTS}

The analysis and interpretation of the results of the articles led to the selection of 21 articles among publications in the period between 2000 and 2009, based on the theme (Figure 1).

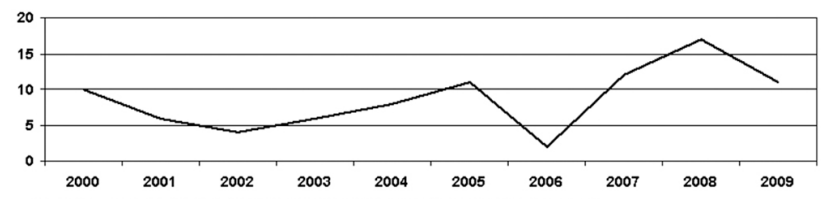

Figure 1. Distribution of publications among period of 2000 to 2009

The areas of knowledge highlighted in the publications on this theme, which totaled 21 articles referring to the risks of alcohol use and dependency, included $6(28.6 \%)$ articles in medical journals; $5(23.8 \%)$ in public health; $4(19 \%)$ in the areas of psychiatry and psychology; $4(19 \%)$ in nursing; and, $2(9.6 \%)$ in specific journals on the use of and dependency on alcohol.

As regards the method employed: $13(61.9 \%)$ used the transversal or cross sectional method; 4 (19\%) were exploratory and descriptive, without specifying the type of research; $3(14.3 \%)$ were review articles; and, $1(4.8 \%)$ was retrospective. Of the articles, $10(47.6 \%)$ were published in Portuguese, 6 (28.6\%) in English, and $5(23.8 \%)$ in Spanish.

Of the remaining subjects of the selected studies, excluding review articles, 10 (55.5\%) were research conducted with adolescents between 10 and 19 years, and $8(44.5 \%)$ included adolescents and adults as subjects. Of these subjects, $11(61.1 \%)$ studies were conducted with high school and university students, plus $3(16.7 \%)$ were with adolescents being monitored for the treatment of alcohol dependency. Also, 4 (22.2\%) articles identified other forms of approaches without specifying the subjects, such as internet access and health care services.

Different instruments were used to measure risk of use, or degree of alcohol dependency, among adolescents. Among those cited in the articles that are recommended by the World Health Organization (WHO), were: AUDIT (Alcohol Use Disorders Identification Test), CAGE (Cut-down, Annoyed, Guilty and Eye-opener), TWEAK (Tolerance, Worry, Eye-opener, Amnesia, Cut down), DUSI (Drug Use Screening Inventory), YRBSS (Youth Risk Behavior Surveillance System), CHAID (Chi-squared automatic interaction detector), RBS (Risk Behavior Survey), Research and Reporting Project on the Epidemiology of Drug Dependence, and the questionnaire of diagnostic identification based on the ICD (International Statistical Classification of Diseases and Related Health Problems), specific for alcohol.

\section{DISCUSSION}

Adolescence is considered a risk factor for alcohol consumption, associated with the conduct developed in this phase of transition to adulthood. Among the influencing factors of the consumption and dependency on alcohol, we understood from the articles analyzed that there are social, environmental and genetic factors. The earlier the initiation, the greater the risk for dependency, which leads to serious consequences ${ }^{(3,10,11)}$.

Researchers claim that alcohol is the most used drug between the various groups of adolescents, followed by tobacco. The beginning of its use occurs on average between 14 to 16 years, with frequent use of the substance from 15 to 44 years, and peaks of higher frequency of consumption between 25 and 42 years, regardless of marital bonds or gender. Alcohol dependency in others is viewed by adolescents as a stigma of an immoral and psychosocial nature, with a predominance of negative images. But the self-perception of their concomitant use shows adolescents do not view it as a drug with great potential for health risks, and many do not classify it as a drug, which demonstrates they feel invulnerable and omnipotent in regard to the substance ${ }^{(12-23)}$. 
Among the articles, it is noted that beer is consumed most by teenagers. The initial use is evidenced by several intrinsic and extrinsic factors, among these are: the influence of the media; troubled relationship with parents; the presence of a family member who uses, usually the father; sexual abuse; low self-esteem; curiosity; and, pressure from peers and friends for reinsertion into their groups. It is also connected to: fun and pleasure, even in isolation; the early initiation of work related to the contact with adults; for better performance and peer acceptance, especially in late adolescence; encouraging experimentation by his own family, for cultural definitions; to improve dissatisfaction with the conditions of life, including those linked to unemployment. Other factors include how to reduce anxiety and stress, motivated by a sense of wellbeing that the drug provides at the beginning of use. Moreover, there is high influence of companions such as colleagues and friends to start using the substance. Thus, this initiation during adolescence is linked to the different vulnerabilities that permeate their lives. These issues make alcohol prone to use, which may evolve into dependency on alcohol in adulthood (11,13, 14, 16, 20,24-26).

With respect to gender, we encountered controversy. Some authors have reported no significant difference between genders, but there is evidence of higher risk of drinking among boys. In relation to the girls who use alcohol, it is confirmed there is increased vulnerability to suffer various forms of violence ${ }^{(13,16,21,27)}$.

In relation to social class, Brazilian studies demonstrate that medium and high social class adolescents are more susceptible to alcohol use, in comparison with those of low social class, which is justified by greater access to social activities and better financial conditions. Moreover, comparative studies between public and private schools regarding the use of the substance observe that the risk is higher in private schools. This is a controversy in relation to studies published in other Latin American countries, which describe that the lower social class presents higher alcohol consumption and justified this by the easy access to bars around the residence, which facilitates the initiation of consumption and purchase. In addition, higher prevalence of consumption was reported in urban areas compared to rural areas, although there is controversy among studies ${ }^{(11,15,16,19,25,28)}$.

The potential risks, identified in the family context, are related to: lack of parental support; liberal parents; a bad or terrible relationship with parents; having suffered maltreatment; and, having experienced domestic violence. Moreover, there was an emphasis on studies that described the genetic inheritance, as a potential risk factor for the use and dependency on alcohol. The published studies report a higher prevalence of use during adolescence from Catholic families or those with no religious practices $(14,18,19,29)$.
With regard to recommendations based on the results of the articles encountered, we observed an emphasis on the necessity of qualification of the public health policies in order to develop programs of prevention, identification and control, aimed at the problems arising from the use of alcohol, primarily, with actions for more effective prevention. To this end, including actions directed to the family and the school environment are crucial, where there are situations of risk for alcohol use. The publications indicate the actions that must be performed within this reality, emphasizing that the professionals who deal with public health should be attentive to the identification of risk and dependency on alcohol, must be qualified to know the particularities of adolescence and substance dependency, and use appropriate language for this age group. The strategies for prevention and control activities should be specific, based on the lived reality of the social context, with educational activities planned for the medium and long term ${ }^{(3,10-19,24,26,29)}$.

\section{CONCLUSION}

The findings evidenced in this review presented the notorious complexity of the theme about the risks for dependency and dependency on alcohol among adolescents. The evidence base showed that it is a common practice among teens between 14 and 16 years, in particular, students from middle and upper classes, who need support and assistance in matters relating to the risks of dependency before there is dependence, with the involvement of family members.

The period of adolescence is marked by a constant learning for the formation of being an adult, leading to physical, psychological and social maturity. The concepts acquired from this phase will provide the foundation for the adult phase, so it is relevant that care that includes psychological and social education of each adolescent; it is a period where there is no comprehensive understanding of the problems that alcohol use can cause long-term.

It was observed that a minority of studies found addressed the prevention of use and alcohol dependence among adolescents, but it is imperative to recommend the importance of intervening on the problem. Just as topic-related publications have increased in recent years, it is necessary that the public health services incorporate strategies based on resolvability of specific actions with emphasis on intra-family and school environments, to prevent its use and identify factors of risk for substance dependency among adolescents.

The knowledge about risks to which adolescents are exposed, by the identification of these factors, becomes possible with several instruments of risk measurement proposed by WHO. In Brazil, public health actions have 
a decentralized focus as a way to be closer to the population, and intervene in the problems identified. Thus, it is for services and health professionals, with greater proximity to the population, to intervene with health education and monitoring of adolescents at risk, as well as their families, and act to control the use of alcohol.

To do this requires performing an individualized assessment through community diagnosis in the catchment area of the performance of health teams, to identify early warning signs and provide punctual information of behaviors related to risks for dependency and actual alcohol dependency. After identifying the problems, it will

\section{REFERENCES}

1. Cordellini JV, Hedi MS, Muraro RF. Protocolo de atenção à saúde do adolescente. 2a ed. Curitiba: Secretaria Municipal da Saúde; 2006.

2. Tiba I. Adolescente, quem ama cuida. 8 a ed. São Paulo: Integrare; 2005.

3. Pechansky F, Szobot CM, Scivoletto S. Uso de álcool entre adolescentes: conceitos, características epidemiológicas e fatores etiopatogênicos. Rev Bras Psiquiatr. 2004; 26 Supl 1: 14-7.

4. Simões C, de Matos MG, Batista-Foguet J. Consumo de substâncias na adolescência: um modelo explicativo. Psicol Saúde Doenças. 2006; 7(2):147-64.

5. Brasil. Ministério da Saúde. Secretaria Nacional de Políticas sobre Drogas. Sistema para detecção do uso abusivo e dependência de substâncias Psicoativas - SUPERA. Brasília (DF): Ministério da Saúde; 2008.

6. Brasil. Ministério da Saúde. Secretaria Nacional de Políticas sobre Drogas. Sistema para detecção do uso abusivo e dependência de substâncias Psicoativas - SUPERA. Brasília (DF): Ministério da Saúde; 2006.

7. Brasil. Ministério da Saúde. Secretaria de Atenção à Saúde. Departamento de Ações Programáticas Estratégicas. Álcool e redução de danos: uma abordagem inovadora para países em transição. Brasília (DF): Ministério da Saúde. 2004; p.29-35.

8. Ganong LH. Integrative reviews of nursing research. Res Nurs Health. 1987; 10(11): 1-11.

9. Burns N, Groves K. The practice of nursing research: conduct, critique and utilization. Philadelphia: WB Saunders; 2001.

10. García Gutiérrez E, Lima Mompó G, Aldana Vilas L, Casanova Carrillo P, Feliciano Álvarez V. Alcoholismo y sociedad, tendencias actuales. Rev Cuba Med Mil [Internet] . 2004 [citado 2010 Dic 5]; 33(3): [cerca de 8 p.] Disponível em: http://scielo.sld.cu/scielo.php?script=sci_ arttext\&pid=S0138-65572004000300007\&lng=es.

11. Silveira CM, Silveira CC, Silva JG, Silveira LM, de Andrade AG, de Andrade LH. Epidemiologia do beber pesado e beber pesado episódico no Brasil: uma revisão sistemática. Rev Psiquiatr Clín. 2008; 35 Supl 1: 31-8.

12. Bertoni N, Bastos FI, de Mello MB, Makuch MY, de Sousa $\mathrm{MH}$, Osis MJ, et al A. Uso de álcool e drogas e sua influência sobre as práticas sexuais de adolescentes de Minas Gerais, Brasil. Cad Saúde Pública. 2009; 25(6): 1350-60.

13. Jinez ML, de Souza JR, Pillon SC. O uso de drogas e fatores de risco entre estudantes de ensino médio. Rev Latinoam Enferm. 2009; 17(2): 246-52.

14. Zenaida M. Uso, abuso, dependencia alcohólica y su relación con el consumo familiar en la población estudiantil del Municipio Palavecino: unidades educativas de básica Lara Venezuela marzo-mayo 2003. Med Fam (Caracas). 2003; 11(2): 14-9. be possible to plan more effective measures to prevent and control it, with greater chances of success.

Preventive actions are possible, when there are effectively trained professionals who assist individuals and / or groups in this age range in order to intervene in risk factors related to family, psychological and social aspects. New studies and research should be conducted to contemplate the effectiveness of preventive actions and the control of alcohol use during adolescence in the core networks from public health services, involving the health team with specific preparation for this type of disease.

15. Baus J, Kupek E, Pires M. Prevalência e fatores de risco relacionados ao uso de drogas entre escolares. Rev Saúde Pública. 2002; 36(1): 40-6.

16. Carlini-Cotrim B, Gazal-Carvalho C, Gouveia N. Comportamento de saúde entre jovens estudantes das redes pública e privada da área metropolitana do Estado de São Paulo. Rev Saúde Pública. 2000; 34(6): 636-45.

17. Strazza L, Azevedo RS, Carvalho HB. Risky behavior regarding drug use and HIV infection: an Internet questionnaire coupled with short education texts for Portuguese speakers. Rev Soc Bras Med Trop. 2007; 40(4): 400-4.

18. Musayón $\mathrm{Y}$, Caufield C. Drug consumption and violence in female work Zapallal - Lima/Peru. Rev Latinoam Enferm. 2005; 13( $\mathrm{N}^{\circ}$ Espec): 1185-93.

19. Ramírez Ruiz M, de Andrade D. La familia y los factores de riesgo relacionados con el consumo de alcohol y tabaco en los niños y adolescentes (Guayaquil-Ecuador). Rev Latinoam Enferm. 2005; 13( No Espec): 813-8.

20. Stanek L. Kraków secondary school students and contemporary threats to human health such as alcoholism and drug addiction. Przegl Lek. 2005; 62(6): 351-3.

21. Tavares BF, Béria JH, de Lima MS. Prevalência do uso de drogas e desempenho escolar entre adolescentes. Rev Saúde Pública. 2001; 35(2): 150-8.

22. Muracén Disotuar I, Martínez Jiménez A, Aguilar Medina JM, González Rodríguez MR. Pesquisaje de alcoholismo en un área de salud. Rev Cubana Med Gen Integr. 2001; 17(1): 62-7.

23. Subramaniam GA, Stitzer MA, Woody G, Fishman MJ, Kolodner, K. Clinical characteristics of treatment-seeking adolescents with opioid versus cannabis/alcohol use disorders. Drug Alcohol Depend. 2009; 99(1-3): 141-9.

24. Peluso ET, Blay SL. Public perception of alcohol dependence. Rev Bras Psiquiatr. 2008; 30(1): 19-24.

25. Pratta EM, dos Santos MA. Adolescence and the consumption of psychoactive substances: the impact of the socioeconomic status. Rev Latinoam Enferm. 2007; 15(No Espec): 806-11.

26. Chiapetti N, Serbena CA. Uso de álcool, tabaco e drogas por estudantes da área de saúde de uma universidade de Curitiba. Psicol Reflex Crít. 2007; 20(2): 303-13.

27. Cruz JM, Etchegaray FB, Yori AN, Dorador IF. Caracterización del beber, problema en estudiantes de educación secundaria de Cauquenes, VII Región, 2006. Rev Méd Maule. 2006;24(2): 51-4.

28. Martino SC, Ellickson PL, McCaffrey DF. Developmental trajectories of substance use from early to late adolescence: a comparison of rural and urban youth. J Stud Alcohol Drugs. 2008; 69(3): 430-40.

29. Tavares BF, Béria JU, de Lima MS. Fatores associados ao uso de drogas entre adolescentes escolares. Rev Saúde Pública. 2004; 38 (6): 787-96. 